\title{
RESIDUES OF POLLUTANTS IN SILURIFORMES FROM VARIOUS LOCALITIES OF THE CZECH REPUBLIC
}

\author{
Z. SVOBODOVÁ ${ }^{1}$, V. PIAČKA ${ }^{1}$, B. VYKUSOVÁ ${ }^{1}$ J. MÁCHOVÁ ${ }^{1}$, M. HEJTMÁNEK ${ }^{2}$, \\ M. HRBKOVÁ ${ }^{3}$, J. BASTL ${ }^{4}$ \\ ${ }^{1}$ Research Institute of Fish Culture and Hydrobiology, Vodňany \\ ${ }^{2}$ Institute of Chemical Technology, Prague \\ ${ }^{3}$ Regional Hygienic Authority, Ceské Budějovice \\ ${ }^{4}$ University of South Bohemia, Faculty of Agriculture, Ceské Budějovice \\ Received February 2, 1995 \\ Accepted May 30, 1995
}

\begin{abstract}
S v o b od ová Z., V. P i a c k a, B. V y k u s ová, J. Má c hová, M. He j t má n e k, M. $\mathrm{H} \mathrm{rb}$ k $\mathrm{v}$ á, J. B a s $\mathrm{l}$ : Residues of Pollutants in Siluriformes from Various Localities of the Czech Republic. Acta vet. Brno 1995, 64: 195-208.

Tissues (muscle, kidney, liver, gonads) were investigated for residues of pollutants in wels (Silurus glanis) from 6 large ponds (Bezdrev, Spolský, Kačlehy, Vrkoč, Novoveský, Bezruč), from Labe river and from the Orlík reservoir and in brown bullhead (Ictalurus nebulosus) from the river Labe. Thirty and 10 individuals of wels were investigated from ponds and the Orlík reservoir, respectively, and 2 individuals from the river Labe. Thirty five individuals of bullhead were investigated from various localities of the Labe. Among pollutants, metals ( $\mathrm{Hg}, \mathrm{Pb}, \mathrm{Cd}, \mathrm{Cu}, \mathrm{Zn}, \mathrm{Cr}, \mathrm{Al}), \mathrm{PCBs}$ as amount of technical mixtures used in the Czech Republic (Delor 103 and Delor 106) and as 7 indicator congeners (K28, K52, K101, K118, K153, K138, K180), DDT and its metabolities, HCB, $\mathrm{HCH}$ isomers, triazines (atrazine, simazine, prometryne, desmetryne, terbutryne) were assessed. The values of individual pollutants found in tissues of wels from ponds were very low and corresponded to hygienic limits in all cases. On the other hand, much higher values of pollutant residues ( $\mathrm{Hg}$ and PCB) were found in wels from the Orlík reservoir, and they exceeded the hygienic limit in some cases (PCB). Values of pollutant residues found in bullhead fished from various localities of the Labe were also increased. Above all, PCB and mercury values exceeded valid hygienic limit of the Czech Republic in some cases.

Wels and brown bullhead proved to be important indicators of loading of various localities of surface waters with investigated pollutants. Wels as a predator and brown bullhead as an omnivorous and benthophagous fish are important indicators of loading of surface waters with mercury. The muscles of wels are besides those of eel (Anguilla anguilla) one of the most important indicators for the evaluation of surface waters loading with polychlorinated biphenyls.
\end{abstract}

Silurus glanis, Ictalurus nebulosus, pond, Labe river, Orlík reservoir, mercury, metals, PCBs, indicator congeners, $D D T, H C B, H C H$, triazines

The objective of this study is to evaluate the suitability of representatives of Siluriformes for indication of water environment loading and to evaluate the hygienic quality of their flesh from the point of view of pollutants content. The representatives of Siluriformes (Silurus glanis, Ictalurus nebulosus) sampled from fish ponds, the river Labe and the Orlík reservoir (Czech Republic) were selected for these investigations.

\section{Materials and Methods}

Residues of pollutants were monitored in Siluriformes from various localities of the Czech Republic. Sample consisting of five individuals of wels (Silurus glanis) were taken from the ponds Bezdrev (460 ha, Fisheries Hluboká nad Vltavou), Spolský (138 ha, Fisheries Třeboň), Kačlehy (136 ha, Fisheries Jindřichův Hradec), Vrkoč (180 ha, Fisheries Pohořelice), Novoveský (120 ha, Fisheries Pohořelice) and Bezruč (100 ha, Fisheries Ostrava) (Fig.1). 
The content of metals $(\mathrm{Hg}, \mathrm{Pb}, \mathrm{Cd}, \mathrm{Cu}, \mathrm{Zn}, \mathrm{Cr}, \mathrm{Al})$, residues of persistent chlorinated hydrocarbons ( $\mathrm{HCB}, \mathrm{a}-\mathrm{HCH}$, b-HCH, g-HCH, o,p-DDE, p,p'-DDE, o,p-DDD, p,p'-DDD, o,p-DDT, p,p'-DDT, PCB as sum of technical mixtures Delor 103, Delor 106 and 7 indicator congeners PCB (K28, K52, K101, K118, K153, K138, K180) and residues of triazines (atrazine, simazine, desmetryne, prometryne, terbutryne) was assessed in muscles, liver, kidneys and gonads of these fish. Altogether 30 individuals of wels (Silurus glanis) from ponds of the Czech Republic were analysed for pollutant residues in 1993.

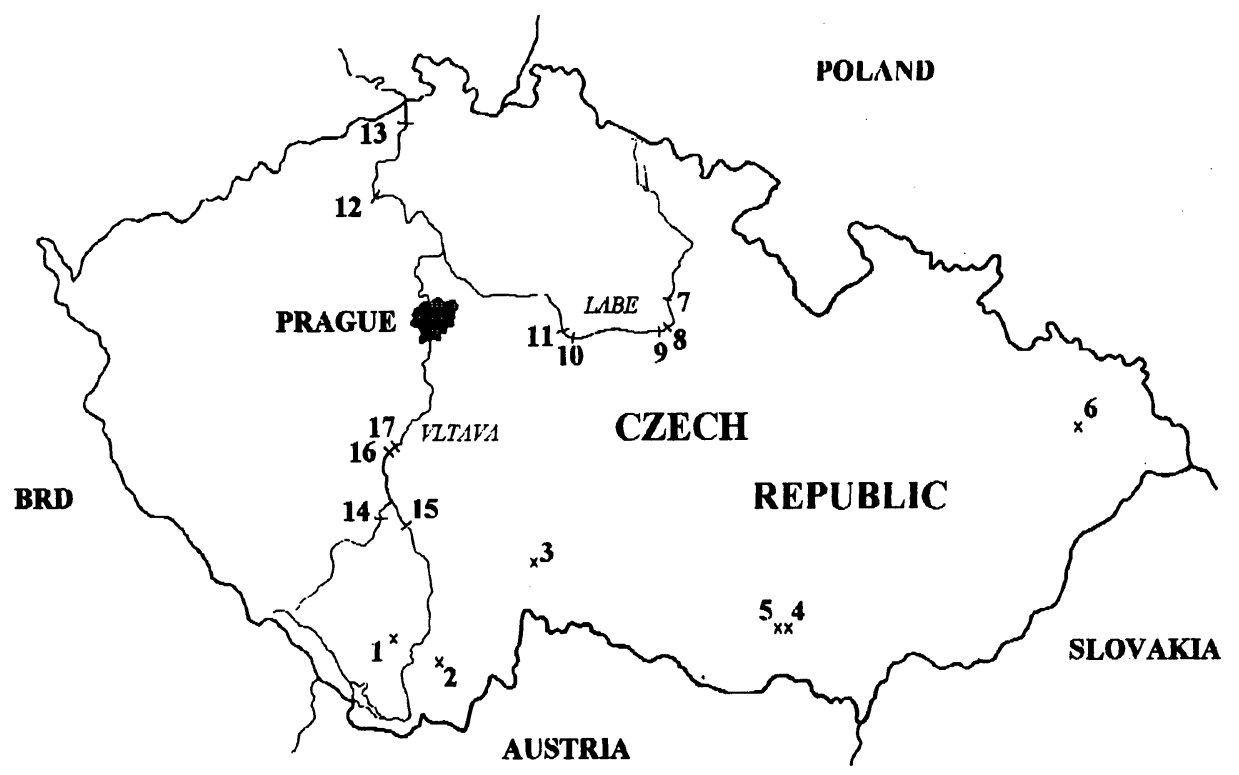

POND
1 - BEZDREV
2 - SPOLSKÝ
3 - KAČLEHY
4 - VRKOČ
5 - NOVOVESKÝ
6 - BEZRUĆ

Fig. 1: Selected localities of the Czech Republic sampled for monitoring of pollutants in fish tissues in the years $1988-1993$

Thirty five individuals of brown bullhead (Ictalurus nebulosus) and 2 specimens of wels (Silurus glanis) were sampled from various localities of the river Labe (Opatovice, Pardubice before it enters and after it leaves the town, Kolín before it enters and after it leaves the town, Lovosice, Děcín - Fig.1) in 1991-1993. Routine methods of ichthyological research of rivers were employed in sampling fish from the Labe. Fish were captured by electroshocking using deepwater electric generator from boat. The content of total mercury and residues of persistent chlorinated hydrocarbons were determined in muscles, liver, kidneys and gonads of the fish under study. Ten specimens of wels (Silurus glanis) were caught with gillnets and by angling in the Orlík reservoir from localities Štědronín, Jehnědno, Žebrákov and dam (Fig.1). The content of total mercury and residues of persistent chlorinated hydrocarbons were determined in muscles, liver, kidneys and gonads of these fish. 
After catching, fish were weighed and samples of tissues were collected immediately. Samples were placed in microtene bags, transported in cooled boxes and deep frozen $\left(-18^{\circ} \mathrm{C}\right)$ in the laboratory. Analyses of tissues for total mercury content were performed by cold steam technique AAS using one-purpose analyser TMA 254. For analysis of other metals $(\mathrm{Pb}, \mathrm{Cd}, \mathrm{Cu}, \mathrm{Zn}, \mathrm{Cr}, \mathrm{Al}), \mathrm{AAS}$ method with previous mineralization of samples by dry procedure using nitric acid and hydrochloric acid at a maximum temperature of $500^{\circ} \mathrm{C}$ was used. Gas chromatography was used as a method for the analysis of residues of persistent chlorinated hydrocarbons (HCB, HCH isomers, DDT and its metabolites, PCB) in fish tissues. The isolation of residues from biological material and cleaning of extracts was performed according to $\mathrm{H} \mathrm{r} \mathrm{u} \mathrm{š} \mathrm{k} \mathrm{a} \mathrm{and} \mathrm{K} \mathrm{o} \mathrm{c} \mathrm{i} \mathrm{á} \mathrm{n} \mathrm{o} \mathrm{vá} \mathrm{(1978)} \mathrm{with} \mathrm{extinction} \mathrm{of} \mathrm{PCB} \mathrm{residues} \mathrm{according} \mathrm{to}$ $\mathrm{K} \mathrm{r} \mathrm{e} \mathrm{d} \mathrm{l}$ and B r e y l (1984). Technical mixtures of Delor 103 (D103) and Delor 106 (D106) served as standards for the determination of PCB residues. Since 1992, congener specific analysis of PCB residues has been performed as well; 7 congeners $\mathrm{K} 28, \mathrm{~K} 52, \mathrm{~K} 101, \mathrm{~K} 118, \mathrm{~K} 153, \mathrm{~K} 138$, and $\mathrm{K} 180$ were used as standards. The analysis of fat content in fish tissues was carried out by aether extraction in Soxhlet apparatus. Residues of individual triazine derivatives (atrazine, simazine, desmetryne, prometryne, terbutryne) were measured after extraction and pre-separation by gas chromatography on capillary columns with thermo-ionizing specific detector by method of outer standard (firm Supel-co).

\section{Results and Discussion}

P ond s

Characteristics of wels (Silurus glanis) from pond culture is given in Table 1. Their age, weight, and values of fat content in tissues are comparable in all of 6 ponds investigated.

Table 1

Characteristics of wels (Silurus glanis) from pond culture analyzed for residues of pollutants in tissues (autumn 1993)

\begin{tabular}{|c|c|c|c|c|c|c|}
\hline \multirow[t]{2}{*}{ Pond } & \multirow[t]{2}{*}{$\mathrm{n}$} & \multirow{2}{*}{$\begin{array}{l}\text { Age } \\
\text { (years) }\end{array}$} & \multirow{2}{*}{$\begin{array}{c}\text { Weight } \\
\text { (g) } \\
x \pm \text { S.D. } \\
\text { var. range }\end{array}$} & \multicolumn{3}{|c|}{ Fat (\%) } \\
\hline & & & & $\begin{array}{c}\text { Muscle } \\
\mathrm{x} \pm \text { S.D. } \\
\text { var. range }\end{array}$ & $\begin{array}{c}\text { Liver } \\
x\end{array}$ & $\begin{array}{c}\text { Eggs } \\
\mathbf{x}\end{array}$ \\
\hline Bezdrev & 5 & $4-5$ & $\begin{array}{l}4820 \pm 1554.7 \\
3250-7250\end{array}$ & $\begin{array}{l}2.02 \pm 2.489 \\
0.51-6.34\end{array}$ & 0.83 & 1.33 \\
\hline Spolský & 5 & 4 & $\begin{array}{l}2390 \pm 114 \\
2250-2500\end{array}$ & $\begin{array}{l}0.87 \pm 0.86 \\
0.21-2.22\end{array}$ & 1.18 & 1.55 \\
\hline Kačlehy & 5 & 4 & $\begin{array}{l}3470 \pm 351.1 \\
3150-4050\end{array}$ & $\begin{array}{l}9.77 \pm 3.518 \\
5.62-15.34\end{array}$ & 1.65 & \\
\hline Vrkoč & 5 & 4 & $\begin{array}{l}3490 \pm 294.5 \\
3250-3900\end{array}$ & $\begin{array}{l}3.13 \pm 2.6 \\
0.58-6.99\end{array}$ & 1.58 & \\
\hline Novoveský & 5 & 4 & $\begin{array}{l}3720 \pm 319.4 \\
3300-4100\end{array}$ & $\begin{array}{l}4.78 \pm 1.633 \\
2.98-6.64\end{array}$ & 0.74 & \\
\hline Bezruč & 5 & 4 & $\begin{array}{l}2540 \pm 507.9 \\
1800-3000\end{array}$ & $\begin{array}{l}7.81 \pm 3.63 \\
3.94-13.76\end{array}$ & 1.44 & \\
\hline
\end{tabular}

\section{Metals}

The comparison of total mercury content in tissues of wels from individual ponds under investigation is presented in Fig. 2. It is evident that the hygienic limit of total mercury content valid in the Czech Republic, i. e. $0.6 \mathrm{mg} . \mathrm{kg}^{-1}$ of muscle was not exceeded in any case. The lowest values of total mercury in muscles and other tissues were found in wels from the ponds Bezruč and Bezdrev, the highest ones in the pond Kačlehy. The sequence of individual tissues according to total mercury content is as follows: muscles $>$ kidneys $>$ liver $>$ gonads. The ratio of total mercury content in the above mentioned tissues is $1: 0.43: 0.35$ : 
0.12 . The mercury content in individual tissues of wels was roughly two-fold compared to values found in tissues of carp (Cyprinus carpio) from the Bezdrev, Spolský and Bezruč ponds in 1991-93 ( $\mathrm{S}$ v o b o d o va et al. 1994a). This fact is related to high accumulation properties of mercury and with the position of wels in food chain. Analyses of bottom sediments were performed in the Bezdrev, Spolský and Bezruč ponds as well. Results of these analyses together with those of fish analyses (wels, common carp) confirmed low contamination of these ponds with mercury. Also the ponds Vrkoč, Novoveský and Kačlehy can be characterized as relatively free of contamination.

Results of analyses of other metals in tissues of wels from individual ponds investigated are given in Figs. 2-4. It is evident that the Czech hygienic limit was not exceeded in any case of lead ( $10 \mathrm{mg} \cdot \mathrm{kg}^{-1}$ of muscles), cadmium $\left(0.05 \mathrm{mg} \cdot \mathrm{kg}^{-1}\right.$ of muscles, $0.5 \mathrm{mg} \cdot \mathrm{kg}^{-1}$ of viscera), copper (10 mg.kg-1 of muscles), zinc (50 mg. $\mathrm{kg}^{-1}$ of muscles) and chromium (0.3 $\mathrm{mg} . \mathrm{kg}^{-1}$ of muscles) contents. Hygienic limit of aluminium content in fish $\left(30 \mathrm{mg} \cdot \mathrm{kg}^{-1}\right)$ was slightly exceeded in muscles of wels from the Spolský, Novoveský and Bezruč, and in liver of wels from the Bezdrev and Spolský. The content of monitored metals in tissues of wels from the individual ponds is comparable. Also values of metals content in tissues of wels and marketable carp from the ponds Bezdrev and Spolský pond are comparable. Similar or slightly higher values of metals (e.g. zinc and chromium) were found in tissues of marketable carp from these ponds (S v o b o d o v á et al. 1993) due to their lower ability for accumulation as compared with mercury. Their content in tissues does not therefore depend on the position of fish species in the food chain.

The accumulation of investigated metals in individual wels tissues was different. The highest content of lead was found in kidneys, followed by gonads, liver and muscles. The ratio of lead content in the above mentioned tissues is roughly $1: 0.93: 0.88: 0.70$. The lead content in tissues of wels from the Spolský and Novoveský was slightly higher as compared with the other ponds.

The sequence of tissues as to the level of cadmium concentration in wels from pond culture was as follows: kidneys > liver > gonads > muscles (the ratio of cadmium content in tissues was roughly: $1: 0.12: 0.08: 0.03$ ). Similarly as in other fish species, the evidently highest content of cadmium was in kidneys. Although the cadmium content in muscles of wels from various ponds is generally comparable, higher values of cadmium content were found in liver and kidneys of wels from the Spolský and Bezruč.

The highest content of copper in wels was found in liver, followed by kidneys, gonads, and the lowest value was in muscles. The ratio of copper in the above mentioned tissues is roughly $1: 0.78: 0.66: 0.24$. The copper content in tissues of wels from the individual ponds was proportionally balanced. Slightly higher content was found in tissues of wels from the Novoveský and in liver of wels from the Bezruč.

Also the zinc content in tissues of wels from individual ponds was proportionally balanced and low. The highest content of zinc was found in eggs, followed by kidneys, milt, liver, and the lowest content was found in muscles. The ratio of zinc content in the above mentioned tissues is roughly $1: 0.56: 0.40: 0.12$.

The chromium content in the respective tissues of wels was almost the same. Also values of chromium in tissues of wels from individual ponds are proportionally balanced and low. Higher values as compared with the other ponds were found in wels from the ponds Spolský and Bezruč.

The sequence of individual tissues of wels according to aluminium content is as follows: kidneys $>$ milt $>$ muscles $>$ liver $>$ eggs (the ratio of Al content in tissues is roughly $1: 0.86$ $: 0.48: 0.46$ ). The values of aluminium content in tissues of wels from individual ponds were quite variable, the highest values were found in tissues of wels from the Spolský and Novoveský.

The metal content in wels tissues from investigated ponds complies with hygienic limits of the Czech Republic and mostly corresponds with values found in carp and other fish species from unloaded ponds. 

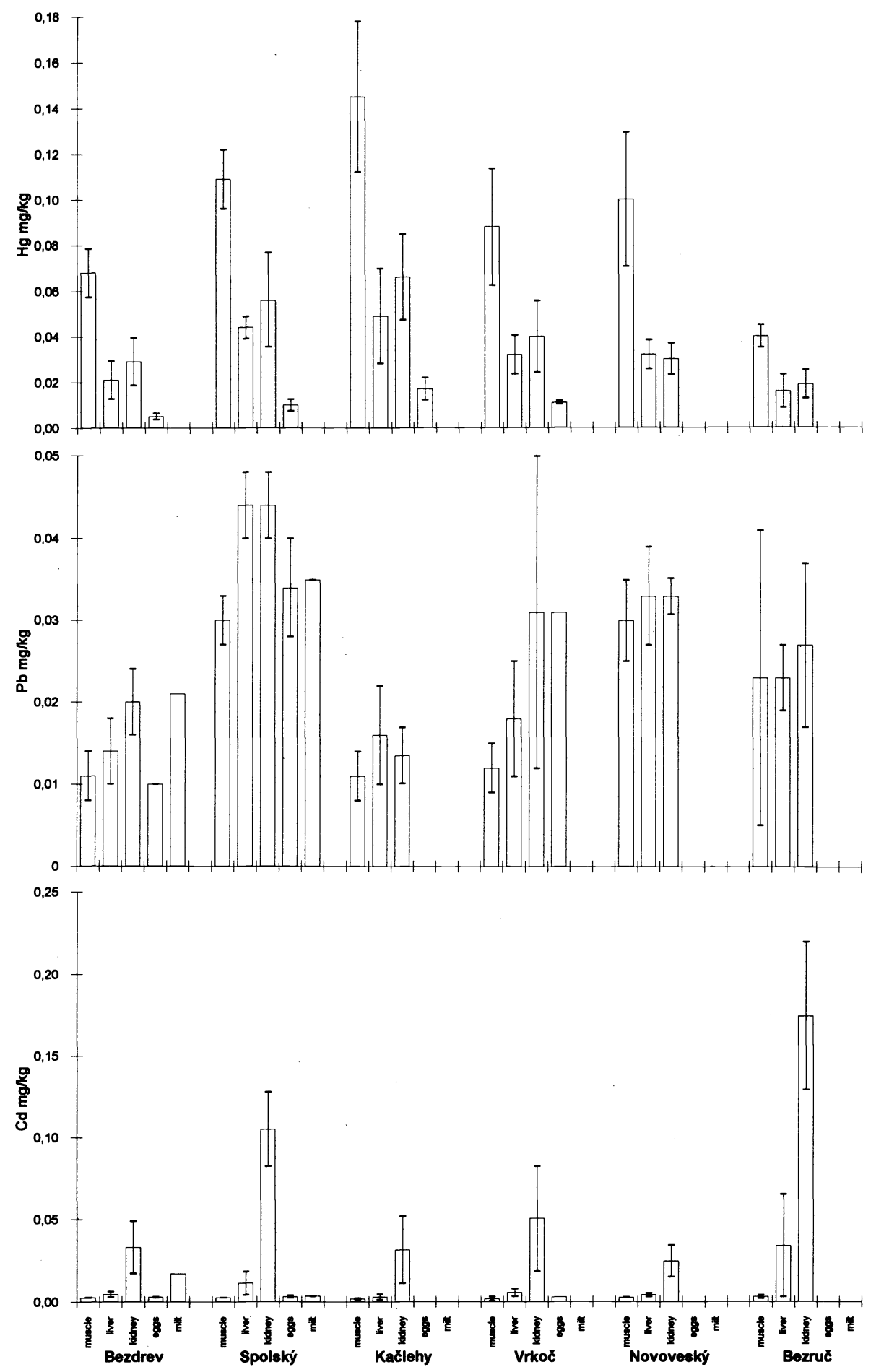

Fig. 2. The content of total mercury, lead and cadmium in tissues of wels (Silurus glanis) from pond culture (autumn 1993) 

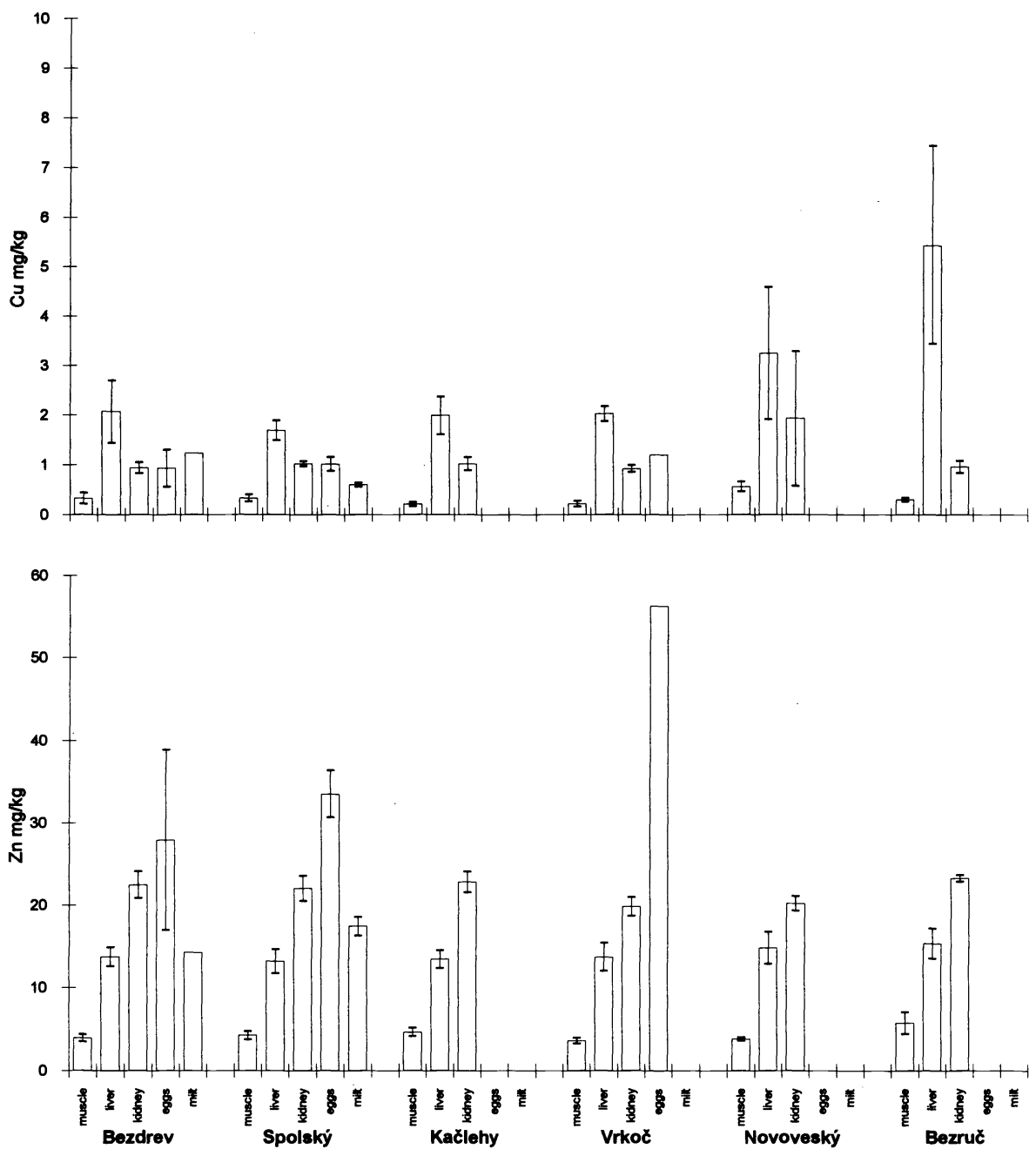

Fig. 3. The content of copper and zinc in tissues of wels (Silurus glanis) from pond culture (autumn 1993)

Persistent chlorinated hydrocarbons

Residues of persistent chlorinated hydrocarbons were determined in muscles and liver. In wels from Bezdrev and Spolský ponds, these residues were assessed also in gonads.

HCB residues were found in tissues of wels from the Bezdrev, Spolský, Kačlehy and Bezruč, the maximum value being $0.003 \mathrm{mg} . \mathrm{kg}^{-1}$. HCB residues were below the level of detection in samples of tissues of wels from the other ponds. Residues of isomers $\mathrm{a}+\mathrm{b}-\mathrm{HCH}$ were below the level of detection ( $<0.001 \mathrm{mg} . \mathrm{kg}^{-1}$ of tissue) in all of analysed samples of fish. Also residues of g-HCH were lower than $0.001 \mathrm{mg} \cdot \mathrm{kg}^{-1}$ in the most of cases, only values of residues of $0.001 \mathrm{mg} . \mathrm{kg}^{-1}$ were found in tissues of wels from the Bezdrev, Spolský and Bezruč, in muscles of wels from Bezdrev and Spolský maximum being $0.003 \mathrm{mg} \cdot \mathrm{kg}^{-1}$. 

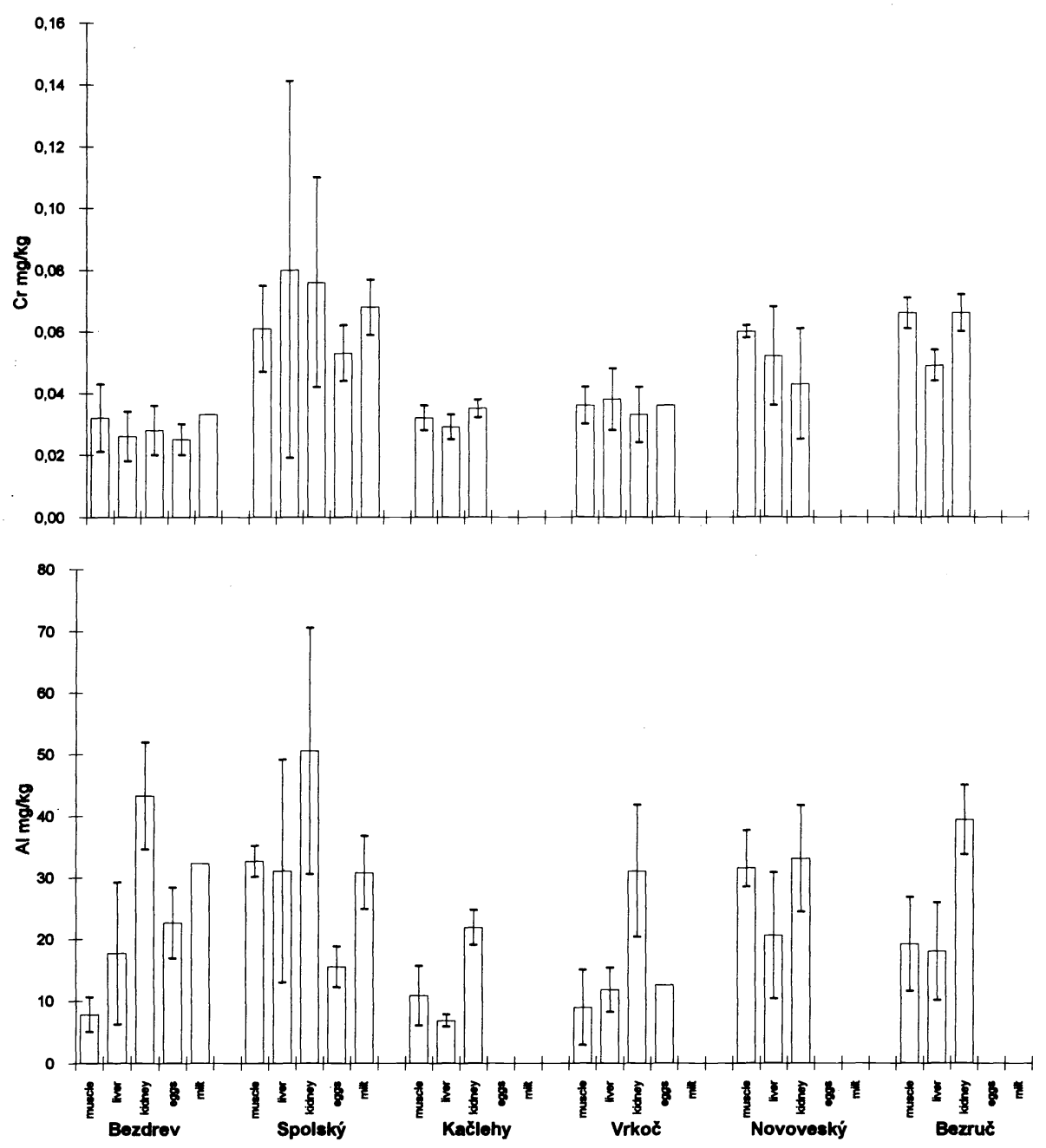

Fig. 4. The content of chromium and aluminium in tissues of wels (Silurus glanis) from pond culture (autumn 1993)

The comparison of the sum of values of DDT and its metabolites in tissues of wels from individual ponds is presented in Fig.5. Our results indicate that the prevailing metabolite is p,p'-DDE, followed by p,p'-DDD and o,p-DDE. Residues of o,p-DDE and p,p'-DDT metabolites were found only in exceptional cases, residues of o,p-DDT were not detected at all. Values of residues in wels from individual ponds are comparable. Higher concentrations of residues of DDT and its metabolites in muscles compared with the values in liver were found in most cases. An adverse situation was found in the ponds Bezdrev and Spolský only.

It is evident from the comparison of HCB residue concentrations and isomers of $\mathrm{HCH}$ and DDT and its metabolites with hygienic limits valid in Germany (HCB $-0.05 \mathrm{mg}^{-\mathrm{kg}^{-1}}$, a+b$\mathrm{HCH}-0.05$ mg.kg-1, $\mathrm{g}-\mathrm{HCH}-0.2 \mathrm{mg} . \mathrm{kg}^{-1}$, sum of DDT and its metabolites $2 \mathrm{mg} . \mathrm{kg}^{-1}$ of fish muscles) that limits were not exceeded in wels from selected ponds in any case. In agreement with literature data (S a c k m a u e r o vá et al. 1977; S v o b o d o vá et al. 1983), higher values of residues of DDT and its metabolites compared with values of HCB and HCH 


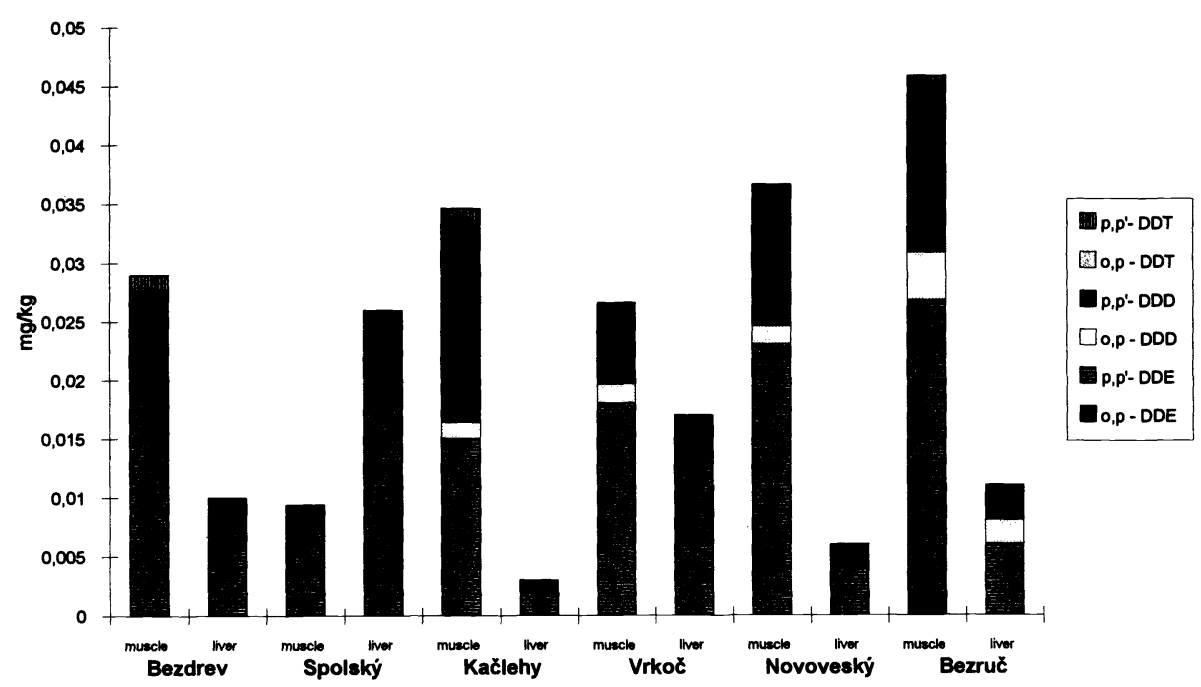

Jig. 5. Residues of sum DDT and its metabolites in tissues of wels (Silures glanis) from pond culture (autumn 1993)

isomers were found in wels from pond culture. This difference is in relation with different accumulation properties. The coefficient of accumulation reached the value of $10^{3}-10^{4}$ in DDT while in $\mathrm{HCB}$ and $\mathrm{HCH}$ it was roughly $10-10^{2}$.

The comparison of values of PCB residues assessed as a sum of technical mixtures of Delor 103 and Delor 106 in wels tissues from investigated ponds is presented in Fig. 6. Similarly as levels of other monitored pollutants, also values of PCB residues in tissues of wels from individual ponds are comparable. The highest values of residues were found in the ponds. Bezdrev and Bezruč. Also concentrations of D103 and D106 were similar in all ponds under study. PCBs with low content of chlorine presented as D103 were below level of detection $(<0.004$ mg. $\mathrm{kg}^{-1}$ ) in all samples. Values of sum of PCBs are consequently comparable with values of PCB residues with higher chlorine content marked as D106. Values of sum of PCB residues measured in all tissues of analysed wels comply with hygienic limit still valid in Czech Republic (0.5 mg. $\mathrm{kg}^{-1}$ of edible parts). Also marketable carp from Bezdrev and Spolský ponds were analysed for PCB residues in autumn 1993 (S v o b o d o v á et al. 1994a). Values obtained in analysis of these fish are comparable with values of wels both from the Bezdrev and Spolský.

The results of monitoring of seven indicator congeners are presented in Fig. 7. Congeners with low content of chlorine $\mathrm{K} 28, \mathrm{~K} 52$ and $\mathrm{K} 118$ were not found in wels tissues. Levels of congeners $\mathrm{K} 101$ and $\mathrm{K} 180$ were also very low, being below the level of detection $\left(<0.001 \mathrm{mg} \cdot \mathrm{kg}^{-1}\right)$ in some samples. Values of congeners K138 and K153 were above the level of detection practically in all of the samples but they were also very low. The highest values of residues of PCB congeners were found in muscles of the biggest wels (7,250 g) caught in the pond Bezdrev (K28-0.001; K52-0.001; K101-0.007; K118<0.001; K153-0.021; K138-0.018; K180-0.012 mg.kg-1).

Values of congeners found in this specimen influenced the average values of residues of individual congeners not only in muscles but also in gonads of wels from the Bezdrev. Valid German limits (K28-0.2; K52-0.2; K101-0.2; K138-0.3; K153-0.3; K180-0.2 mg.kg-1 of muscles) were not exceeded in any case, not even in the biggest wels from pond culture.

Values of residues of indicator congeners in tissues of wels from individual ponds were low and relatively balanced. The highest values were found in the Bezdrev (influenced by the wels of highest body mass) followed by the pond Bezruč. Similarly as in wels, no congeners K28, K52 and K118 were found in marketable carp from Bezdrev and Spolský ponds (S v o b o d o vá et al. 1994a). The sum of congeners in muscles of marketable carp from the Spolský was comparable with the value found in muscles of wels. The average values of sum of congeners in 


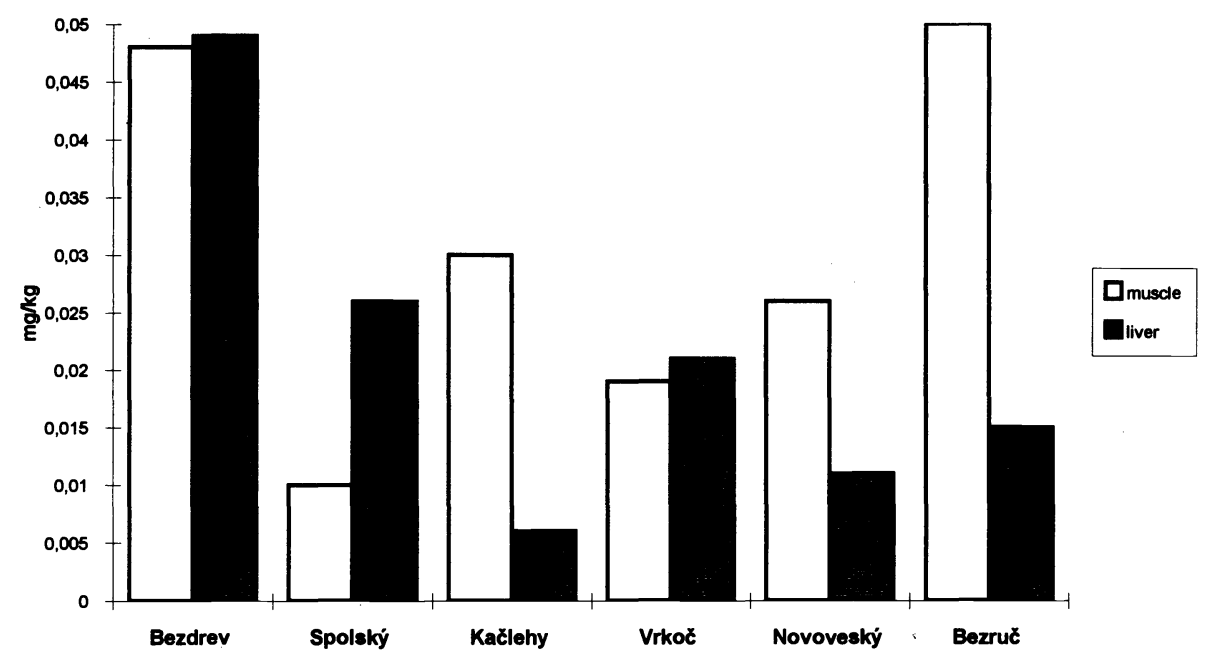

Fig. 6. PCB residues expressed as sum of technical mixtures (D103 + D106) in tissues of wels (Silurus glanis) from pond culture (autumn 1993)

muscles of carp and wels from the Bezdrev were 0.003 and 0.017 mg.kg ${ }^{-1}$, respectively.

Values of the sum of D103+D106 found in tissues of pond wels are roughly 2.1-3.4fold higher as compared with values of sum of indicator congeners. Similar ratio of sum of D103+D106 and of indicator congeners was found also in muscles of carp from the ponds Bezdrev and Spolský (S v o b o d o vá et al. 1994a).

Based on the results of the analyses of wels tissues, all of the six ponds investigated can be considered as relatively free of persistent chlorinated hydrocarbons as indicated by comparison of residues with values measured in other fish species, especially in carp from non-loaded ponds.

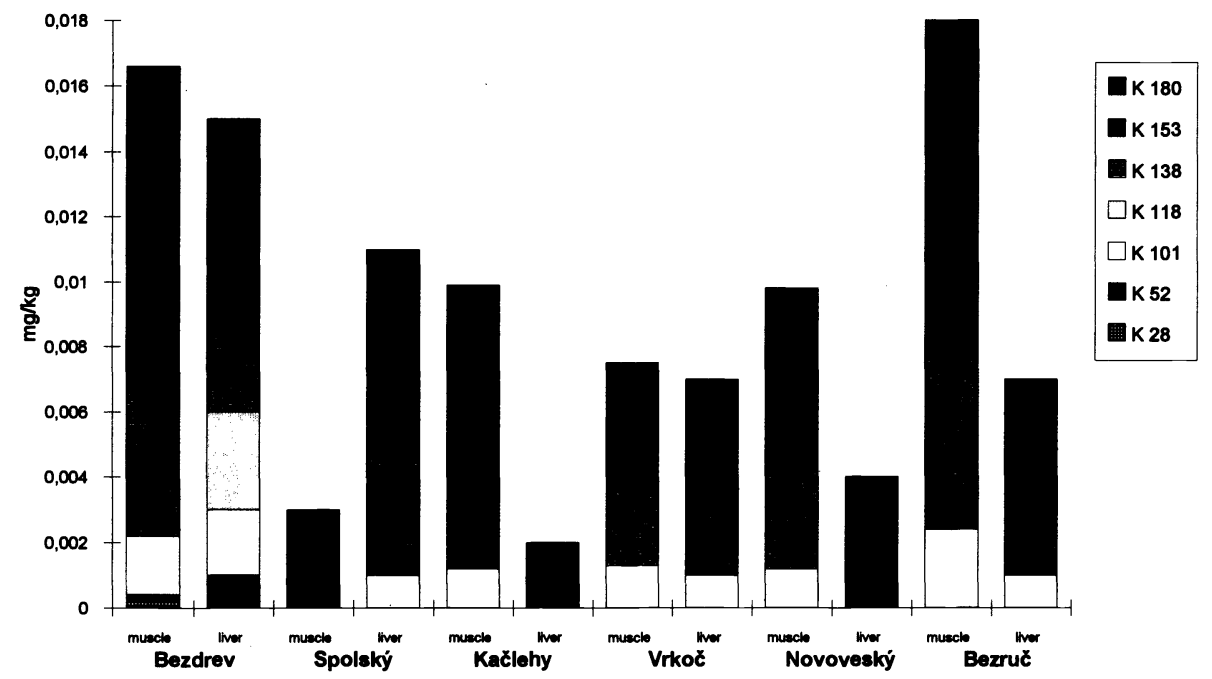

Fig. 7. PCB residues expressed as sum of indicator congeners (K 28, K 52, K 101, K 138, K 153 and K 180) in tissues of wels (Silurus glanis) from pond culture (autumn 1993) 
Table 3

Residues of persistent chlorinated hydrocarbons in tissues of wels (Silurus glanis) and brown bullhead (Ictalurus nebulosus) sampled from various localities of the river Labe and Orlík dam lake

\begin{tabular}{|c|c|c|c|c|c|c|c|c|c|c|c|c|}
\hline \multirow[t]{2}{*}{ Localities } & \multirow[t]{2}{*}{ Fishes } & \multirow[t]{2}{*}{ Year } & \multirow[t]{2}{*}{$\mathbf{n}$} & \multirow{2}{*}{$\begin{array}{l}\text { Weight (g) } \\
x \pm \text { S.D. } \\
\text { var. range }\end{array}$} & \multirow[t]{2}{*}{ Tissue } & \multirow{2}{*}{$\begin{array}{l}\text { Fat } \\
(\%)\end{array}$} & \multicolumn{6}{|c|}{$\mathrm{mg} / \mathrm{kg}$} \\
\hline & & & & & & & D 103 & D 106 & sum PCB & $\begin{array}{l}\mathrm{HCB} \\
\mathrm{HCH}\end{array}$ & gamma & sum DDT \\
\hline \multicolumn{13}{|l|}{ Labe } \\
\hline \multirow{3}{*}{$\begin{array}{l}\text { Pardubice } \\
\text { (before town) } \\
\text { Dexín }\end{array}$} & S. glanis & 1992 & 1 & 350 & muscle & 2.65 & 0.092 & 0.539 & 0.631 & 0.009 & 0.006 & 0.114 \\
\hline & I. nebulosus & 1991 & 9 & $\begin{array}{l}196 \pm 81.6 \\
110-347\end{array}$ & muscle & 1.37 & 0.004 & 0.354 & 0.354 & 0.077 & 0.001 & 0.038 \\
\hline & & & 4 & $\begin{array}{l}248 \pm 95 \\
152-347\end{array}$ & eggs & 7.81 & 0.004 & 1.937 & 1.937 & 0.334 & 0.001 & 0.289 \\
\hline \multicolumn{13}{|l|}{ Orlík } \\
\hline \multirow[t]{2}{*}{ Stexdronín } & S. glanis & 1988 & 1 & 3500 & muscle & 5.79 & 0.390 & 0.531 & 0.921 & & & \\
\hline & S. glanis & 1990 & 3 & $\begin{array}{l}1867 \pm 208 \\
1700-2100\end{array}$ & muscle & 4.39 & 0.004 & 0.147 & 0.147 & & & \\
\hline \multirow[t]{4}{*}{ Jehnědno } & S. glanis & 1989 & 1 & unknown & muscle & 4.70 & 0.728 & 3.299 & 4.027 & & & 1.242 \\
\hline & & & & & liver & 3.42 & 0.531 & 1.722 & 2.253 & & & 0.651 \\
\hline & & & & & eggs & 1.70 & 0.170 & 0.906 & 1.076 & & & 0.360 \\
\hline & S. glanis & 1990 & 1 & 32000 & muscle & 12.10 & 0.029 & 0.264 & 0.293 & & & \\
\hline \multirow{4}{*}{$\begin{array}{l}\text { Žebrákov } \\
\text { dam }\end{array}$} & S. glanis & 1988 & 1 & 4800 & muscle & 0.76 & 0.055 & 0.188 & 0.243 & & & \\
\hline & S. glanis & 1991 & 1 & 1700 & muscle & 1.01 & 0.035 & 0.041 & 0.076 & 0.001 & 0.002 & 0.028 \\
\hline & S. glanis & 1991 & 1 & 3300 & muscle & 4.54 & 0.004 & 0.583 & 0.583 & 0.004 & 0.006 & 0.154 \\
\hline & & & 1 & 3300 & liver & 3.18 & 0.020 & 0.184 & 0.204 & 0.001 & 0.002 & 0.057 \\
\hline
\end{tabular}

\section{Triazines}

Residues of triazines were determined in muscles of marketable wels sampled from individual investigated ponds. No value exceeding the level of detection of individual triazine derivatives (atrazine and simazine $<0.001$; desmetryne, prometryne and terbutryne $<0.005$ mg. kg ${ }^{-1}$ ) was found in any of analysed samples. No residues of triazine derivates were detected in marketable common carp and grass carp (Ctenopharyngodon idella) from Bezdrev pond in 1993. Low values of atrazine residues were found in muscles of marketable common carp from the Spolský $\left(0.016 \mathrm{mg} . \mathrm{kg}^{-1}\right)$ in $1993(\mathrm{~S}$ v o b o d o v á et al. 1994a).

\section{The river Labe}

In contrast to wels from ponds, much higher values of residues of monitored pollutants were found in brown bullhead (Ictalurus punctatus) and wels (Silurus glanis) from the river Labe.

\section{Mercury}

The comparison of values of total mercury content in tissues of brown bullhead from the Labe is presented in Fig. 8. The weight of fish investigated varied between $60-220 \mathrm{~g}$, and no evident differences in fish weight were observed between individual localities. A marked increase was measured in total mercury content namely in the sector between localities Pardubice downstream and Kolín upstream. Such remarkable increase of total mercury content was detected also in tissues of other non-predatory and predatory fish species ( $\mathrm{S}$ v o b o d o v a ét al. 1994b). Therefore the above-mentioned sector can be considered as a locality with high loading of aquatic ecosystem with mercury. It was shown that brown bullhead as omnivorous and benthophagous fish species can be considered as a very important indicator of loading of aquatic environment with mercury. Individual tissues of brown 
bullhead can be rated according to the values of total mercury content as follows: muscles $>$ parenchymatous organs (liver, kidneys) $>$ gonads (eggs). The valid Czech limit of total mercury content (i.e. $0.1 \mathrm{mg} \cdot \mathrm{kg}^{-1}$ ) was exceeded in muscles of brown bullhead from the Labe practically in all cases.

Besides brown bullhead, also two wels specimens from the Labe were analysed in localities Pardubice upstream and downstream (Table 2). Both of them were of lower weight and originated from localities of the river Labe less contaminated with mercury. Also values of total mercury content in muscles and other tissues of wels are comparable with values found in fish from localities of running waters relatively unload.

\section{Persistent chlorinated hydrocarbons}

The river Labe is characteristic by relatively high contamination with chlorinated hydrocarbons, above all polychlorinated biphenyls with higher chlorine content ( $\mathrm{S}$ v o b od o vá et al. 1993). The results of analyses of tissues of wels from locality Pardubice upstream and of brown bullhead from locality Děčín (Table 3) confirm this fact. PCBs with high chlorine content (D106) prevailed in fish from both localities. Still valid hygienic limit in the Czech Republic $\left(0.5 \mathrm{mg} . \mathrm{kg}^{-1}\right)$ was exceeded in muscles of wels from locality Pardubice upstream and several times higher values were found also in eggs of brown bullhead from locality Děčín. Also residues of chlorinated pesticides were much higher in tissues of Siluriformes from the Labe as compared with values found in wels from pond culture (Table 3). Especially in eggs of brown bullhead with high fat content, high values of HCB residues were found. Residues of chlorinated pesticides $(\mathrm{g}-\mathrm{HCH}$, DDT and its metabolites) in other samples were at the level of values routinely found in localities of running waters.

\section{The Orlik reservoir}

The Orlík reservoir situated on the river Vltava has a large catchment area and concentrates water practically from the whole region of Southern and partly also Western Bohemia. This reservoir is characteristic by relatively high loading with various pollutants. This is demostrated above all by findings of higher values of pollutants in fish tissues.

\section{Mercury}

Five specimens of wels were analysed for total mercury content (Table 2). Although the detected values did not exceed the Czech limit $\left(0.6 \mathrm{mg} . \mathrm{kg}^{-1}\right)$, they can be considered as increased. The highest values of total mercury content were found in muscles, followed by liver, kidneys and gonads. As compared with values found in wels from pond culture, the values of total mercury content in tissues of wels from the Orlík reservoir were approximately 5 times higher although the weight of wels from the Orlík reservoir was mostly lower than that of wels from pond culture. P i a c k a et al. (1994) presents the values of total mercury content in tissues of various fish species from different localities of the Orlík reservoir. Wels is considered here as a well suitable fish to indicate mercury loading. 


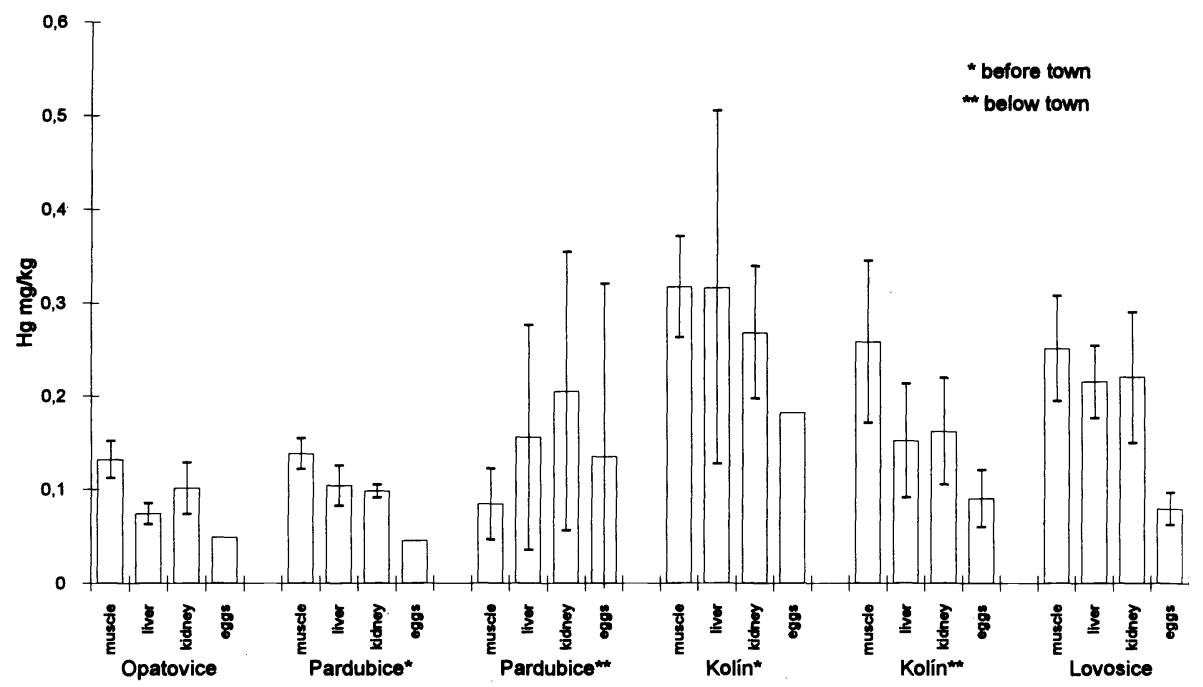

Fig. 8: The content of total mercury in tissues of brown bullhead (lctalurus nebulosus) from various localities of the river Labe (*upstream the town, **downstream the town)

Table 2

The content of total mercury in tissues of wels (Silurus glanis) sampled from various localities of the river Labe and the Orlík reservoir

\begin{tabular}{|l|c|c|c|c|c|c|c|}
\hline Localities & Year & $\mathrm{n}$ & \multirow{2}{*}{$\begin{array}{c}\text { Weight } \\
(\mathrm{g})\end{array}$} & & \multicolumn{4}{|c|}{ Hg (mg/) } \\
\cline { 5 - 8 } & & & & Muscle & Liver & Kidney & Eggs \\
\hline Labe-Pardubice & 1992 & 1 & 350 & 0.209 & 0.071 & 0.084 & 0.017 \\
(upstream the town) & & & & & & & \\
Labe-Pardubice & 1992 & 1 & 250 & 0.113 & 0.174 & 0.159 & \\
(downstream & & & & & & & \\
the town) & & & & & & & \\
Orlík-Stědronín & 1990 & 1 & 2100 & 0.551 & 0.357 & 0.241 & \\
& 1990 & 1 & 1700 & 0.446 & 0.341 & 0.261 & \\
Orlík-dam & 1991 & 1 & 1700 & 0.383 & 0.221 & 0.183 & 0.084 \\
& 1991 & 1 & 3300 & 0.445 & 0.175 & 0.194 & \\
& 1991 & 1 & 5700 & 0.391 & 0.288 & 0.14 & \\
& & & & & & & \\
\hline
\end{tabular}

Persistent chlorinated hydrocarbons

The Orlík reservoir is heavily loaded with polychlorinated biphenyls. It results from the values of $\mathrm{PCB}$ residues in wels presented in Table 3 and their comparison with values found in pond wels. PCBs with high chlorine content (D106) prevail very expressively in all analysed samples of wels from the Orlík reservoir. Hygienic limit of PCB content in muscles 
(0.5 mg.kg-1 as sum of PCB in edible parts) was exceeeded in three of nine specimens investigated. Very high values were found in wels $(32 \mathrm{~kg})$ from locality Jehnědno. Hygienic limit was exceeded 8-times in this wels. High indication ability of wels is evident from comparison of values of PCB residues in tissues of this species with other fishes from the Orlík reservoir ( $\mathrm{S}$ v o b od o vá et al. 1994c). Besides muscles of eel (Anguilla anguilla), flesh of wels is the most important indicator of loading of reservoirs with polychlorinated biphenyls.

Contamination of the Orlík reservoir with chlorinated pesticides, monitored after analyses of tissues of wels (Table 3), can be considered as comparable with other localities of running waters and reservoirs in the Czech Republic.

\section{Rezidua polutantů u sumcovitých ryb odlovených v různých lokalitách České republiky}

Na rezidua polutantů byly vyšetřeny tkáně (svalovina, ledviny, játra a gonády) sumce velkého (Silurus glanis) ze šesti velkých rybníkủ (Bezdrev, Spolský, Kačlehy, Vrkoč, Novoveský, Bezruč), z řeky Labe a z údolní nádrže Orlík a tkáně sumečka amerického (Ictalurus nebulosus) z řeky Labe. Vyšetřeno bylo 30 kusů sumců velkých z rybníků, 10 kusů sumců velkých z údolní nádrže Orlík, 2 kusy sumcủ velkých z reky Labe a 35 kusů sumečkủ amerických z různých lokalit řeky Labe. Stanoveny byly kovy $(\mathrm{Hg}, \mathrm{Pb}, \mathrm{Cd}, \mathrm{Cu}$, $\mathrm{Zn}, \mathrm{Cr}, \mathrm{Al}$ ), PCB jako technické směsi používané v České republice (Delor 103 a Delor 106) a jako 7 indikátorových kongenerů (K28, K52, K101, K118, K138, K153, K180), DDT a jeho metabolity, HCB, izomery HCH a triaziny (atrazin, simazin, prometryn, desmetryn, terbutryn). Nalezené hodnoty jednotlivých polutantů v tkáních sumců velkých z rybníků byly velmi nízké a ve všech případech vyhovovaly platnému hygienickému limitu. Výrazně vyšši hodnoty reziduí polutantů (Hg a PCB) byly nalezeny u sumců velkých $\mathrm{z}$ údolní nádrže Orlík, a v některých případech překračovaly hygienické limity. Rovněž zvýšené byly hodnoty polutantů naměřené u sumečků amerických odlovených $\mathrm{z}$ různých lokalit řeky Labe. Především hodnoty PCB a rtuti převyšovaly v některých př́ípadech hygienické limity platné v ČR. Sumec velký jako predátor a sumeček americký jako omnivorní a bentofágní ryba jsou významnými indikátory znečištění povrchových vod sledovanými polutanty, zejména rtutí a PCB. Svalovina sumce velkého je vedle svaloviny úhoře říčního (Anguilla anguilla) jedním z nejvýznamnějších indikátorů pro hodnocení zněčištění povrchových vod polychlorovanými bifenyly.

\section{Acknowledgements}

This study was supported from grant No. GA 203/93/2387 (GA Czech Republic)

\section{References}

HRUŠKA J., KOCIÁNOVÅ M. 1978: The assessment of residues of chlorinated pesticides in foodstuffs, biological material and water using gas chromatography. Průmysl potravin 29: 49-51

KREDL F., BREYL J. 1984: Rapid routine method of PCB assessment in flesh and meat products. Acta hyg. epidem. mikrobiol. 10:59-62.

PIAČKA V., SVOBODOVÁ Z., VYKUSOVÁ B., MáCHOVÁ J., HEJTMÁNEK M. 1994: Total mercury content in fish from Orlík reservoir. Mikroelementy 94 (in press)

SACKMAUEROVÁ M., PALUŠOVÁ O., SZOKOLAY A., NEMÁK J. 1977: The dynamics of residues of organochlorinated pesticides in biocenosis of Danube river. Agrochémia 17: 46-48

SVOBODOVA Z., HRBKOVÁ M., VOSTRADOVSKÝ J. 1983: Chlorinated hydrocarbon residues in fish caught in the Lučina dam lake and in the drainage area of the Berounka river. Bulletin VÚRH Vodňany 19: 8-16

SVOBODOVÁ Z., PIAČKA V., VYKUSOVÁ B., MÁCHOVÁ J. 1994a: The evaluation of health unexpec- 
tionability of pond fish in connection with the ecological loading of aquatic environment. Project report, RIFCH Vodřany, 22 p.

SVOBODOVÁ Z,. VYKUSOVÁ B., PIAČKA V., MÁCHOVÁ J. 1994b: The content of selected pollutants in fish from Labe river and its tributaries. Project report, RIFCH Vodñany, $17 \mathrm{p}$.

SVOBODOVÁ Z., VYKUSOVÁ B., PIAČKA V., MÁCHOVÁ J., HRBKOVÁ M., VOSTRADOVSKÝ J. 1994c: Residues of PCB in fish and other items of aquatic ecosystem of Skalice river, and Orlík and Kamýk reservoirs. Project report, RIFCH Vodňany, $16 \mathrm{p}$. 